\title{
Emerging trends in sociology of tourism
}

\begin{abstract}
Tourism is an invisible export in that it creates a flow of foreign currency into the economy of a destination country, thereby contributing directly to the current account of the balance of payments. Like other export industries, this inflow of revenue creates business turnover, household income, employment, and government revenue. However, the generation process does not stop at this point. Some portion of the money received by the business establishments, individuals, and government agencies is resent within the destination economy, thereby creating further rounds of economic activity. These secondary effects can in total considerably exceed in magnitude the initial direct effects. Indeed any study purporting to show the economic impact made by tourism must attempt to measure the overall effect made by the successive rounds of economic activity generated by the initial expenditure. The process has been documented with attention drawn to the strengths, weaknesses, and limitations of the various approaches.1 Domestic tourism has somewhat similar economic effects on the host regions of a country. Whereas, however, international tourism brings a flow of foreign currency into a country, domestic tourism redistributes currency spatially within the boundaries of a country. From the point of view of a tourist region within a country, however, domestic tourism is a form of invisible export. Money earned in other regions is spent within the host region creating additional business revenue, income, jobs, and revenue to local government. The process of secondary revenue, income, and employment generation within the host region is then the same as for a national economy. The principal difference during these secondary stages, however, is that individual regions within a country are usually less economically self-contained, and, hence, a far greater proportion of the money is likely to leak out of the regional system into other regions.

The secondary effects in individual regions are far lower in magnitude than for the national economy as a whole. Moreover, tourism seems to be more effective than other industries in generating employment and income in the less developed, often peripheral, regions of a country where alternative opportunities for development are more limited. Indeed, it is in these areas that tourism can make its most significant impact. In such places many of the local people are subsistence farmers or fishermen, and if they become involved in the tourism industry their household incomes increase by a very large amount. The growth of tourism in such areas may provide also a monetary incentive for the continuance of many local crafts, whereas the tourist hotels may create a market for local produce. Indeed, the introduction of a tourism industry into such areas can have a proportionally greater effect on the welfare of the resident population than the same amount of tourism might have on the more developed parts of the same country. The paper is an attempt to look into the emerging trends in Sociology of tourism.
\end{abstract}

Keywords: tourism, currency, industry, migration, employment opportunities, activity
Volume 2 Issue 3 - 2018

\author{
Vikramendra Kumar \\ Department of Sociology, University of Delhi, India
}

Correspondence: Vikramendra Kumar, Department of Sociology, Delhi School of Economics, University of Delhi, Delhi, India, Email Bardhan.vikramendra@gmail.com

Received: January 17, 2018 | Published: June 12, 2018

\section{Introduction}

Travel has existed since the beginning of time when primitive man set out, often traversing great distances, in search of game that provided the food and clothing necessary for his survival. Throughout the course of history, people have travelled for purposes of trade, religious conviction, economic gain, war, migration, and other equally compelling motivations. In the Roman era, wealthy aristocrats and high government officials also travelled for pleasure. Seaside resorts located at Pompeii and Herculaneum afforded citizens the opportunity to escape to their vacation villas in order to avoid the summer heat of Rome. Travel, except during the Dark Ages, has continued to grow, and throughout recorded history has played a vital role in the development of civilizations. Tourism as we know it today is distinctly a twentieth-century phenomena. Historians suggest that the advent of mass tourism began in England during the industrial revolution with the rise of the middle class and relatively inexpensive transportation. The creation of the commercial airline industry following World War II and the subsequent development of the jet aircraft in the 1950s signaled the rapid growth and expansion of international travel. This growth led to the development of a major new industry: tourism. In turn, international tourism became the concern of a number of world governments because it not only provided new employment opportunities, but it also produced a means of earning foreign exchange. Today tourism has grown significantly in both economic and social importance. The fastest growing economic sector of most industrialised countries over the past several years has been in the 
area of services. One of the largest segments of the service industry, although largely unrecognised as an entity in some of these countries, is travel and tourism. According to the World Travel \& Tourism Council (2003) (WTTC), travel and tourism is the biggest industry in the world on virtually any economic measure, including gross output, value added, capital investment, employment, and tax contributions. In 2003, the industry's gross output was estimated to be in excess of US $\$ 4.5$ billion of economic activity (total demand), more than 10 percent of the total gross national product spending.

The development of tourism, especially in a previously underdeveloped part of a country, requires the existence of an infrastructure, as well as hotel accommodation and other facilities specific to tourism. In many cases these utilities are economically indivisible in the sense that, in providing them for the tourism industry, they at the same time become available for the use of local people. Thus, in many countries, highways and airfields, constructed primarily to cater for tourism, now provide an access to wider markets for many locally produced goods. Unfortunately, in many cases the local people still receive little direct benefit from these developments. This in essence is a problem of both physical and economic distribution (i.e., of the extent to which, and the speed at which, these facilities should be made more generally available). As tourism continues to grow in a region, it makes increasing demands on the scarce resources of that area. Land in particular is required and in consequence land prices rise. Farmers and other local landowners are encouraged to sell, with the result that, although they may obtain short term gains, they are left landless with only low paid work available. Indeed much of the benefit from higher land prices may accrue to speculators who buy land from the previous owners before it has been scheduled for development.

These problems can be overcome, however, if either the land is acquired at an early stage by the government for a fair, market price or if the land is rented rather than sold to the developers. Market forces do not necessarily ensure that development keeps pace with demand. There is a need for realistic planning and the effective enforcement of planning regulations to reduce possible conflicts of interest and, where appropriate, to conserve unique and unusual features for the enjoyment of future generations of visitors and residents alike. This is a lesson that has been learned rather late in many developed countries. Superficially at least the economic 'benefits' of tourism seem selfevident. Yet in recent years several writers have expressed reservations about the nature and size of the benefits attributable to tourism and have become increasingly skeptical about the potentialities of tourism as a tool for development and growth and as a means of maximizing the welfare of the indigenous population. For example, Tosun et al., that although tourism as an economic development strategy in Turkey has increased the rate of economic development, it has also created inequalities between Turkish regions and social classes. In particular this was caused by the approach of offering economic incentives for mass coastal tourism developments at the expense of rural areas. The problem is essentially one of resource allocation and of whether or not the development of a tourism industry offers the optimum usage of the resources available in other words an assessment of the costs and benefits of tourism development vis-à-vis alternatives.

However, one of the major problems of the travel and tourism industry that has hidden or obscured its economic impact is the diversity and fragmentation of the industry itself. The travel industry includes hotels, motels, and other types of accommodation; restaurants and other food services; transportation services and facilities; amusements, attractions, and other leisure facilities; gift shops; and a large number of other enterprises. Because many of these businesses also serve local residents, the impact of spending by visitors can easily be overlooked or underestimated. In addition, $\mathrm{Meis}^{3}$ points out that the tourism industry involves concepts that have remained amorphous to both analysts and decision makers. Moreover, in all nations, this problem has made it difficult for the industry to develop any type of reliable or credible tourism information base in order to estimate the contribution it makes to regional, national, and global economies. However, the nature of this very diversity makes travel and tourism an ideal vehicle for economic development in a wide variety of countries, regions, or communities. Once the exclusive province of the wealthy, travel and tourism have become an institutionalised way of life for most of the world's middleclass population. In fact, McIntosh et al., ${ }^{4}$ suggest that tourism has become the largest commodity in international trade for many world nations, and for a significant number of other countries it ranks second or third. For example, tourism is the major source of income in Bermuda, Greece, Italy, Spain, Switzerland, and most Caribbean countries. In addition, Hawkins \& Ritchie, ${ }^{5}$ quoting from data published by the American Express Company, suggest that the travel and tourism industry is the number one ranked employer in Australia, the Bahamas, Brazil, Canada, France, [the former] West Germany, Hong Kong, Italy, Jamaica, Japan, Singapore, the United Kingdom, and the United States. Because of problems of definition that directly affect statistical measurement, it is not possible with any degree of certainty to provide precise, valid, or reliable data about the extent of worldwide tourism participation or its economic impact. In many cases, similar difficulties arise when attempts are made to measure domestic tourism.

Tourism economics has been a rapidly expanding subject over the past decade or so-this is partly a reflection of the increasing interest in tourism research generally. Tourism papers are published in tourism and in economics journals, and there is now a specialist journal, Tourism Economics, devoted to it. There are several texts on the subject as well. What specific contribution is tourism economics making? Tourism economics is not so much a new branch of economics, but rather it is an industry- or sector-based area of work which draws on, and applies,

developments in general economics. In this respect, it is like transport or energy economics. As with these areas, there are some aspects of tourism economics which have been, or are becoming, of particular importance, in the way that choice modelling is a characteristic and important aspect of transport economics. Tourism economics draws on several, mainly microeconomic, branches of economics and econometrics, such as demand modelling, taxation theory, environmental economics, human capital theory and industrial organisation. More recently, it has been drawing on trade theory and general equilibrium modelling. Recent developments in tourism economics have taken one of a number of forms. There are some areas which have been part of the traditional content of tourism economics which are being made more rigorous. Perhaps the best example of this is in demand analysis and forecasting. This has long been an important aspect of the subject, with many contributions, with a distinct emphasis on obtaining practical empirical results. Research in this field has been made more rigorous, and results made more reliable, by the use of advanced econometric specification and testing. This is illustrated in the two chapters by Lim and by Song 
and Turner. Taxing and pricing issues have also formed part of the content of the subject, and these have been informed by developments in taxation theory, pricing and infrastructure analysis, as the chapters by Mak, Sakai and Loomis and Lindberg show. So far, the analysis of the supply side of tourism has not attracted as much attention as the demand side-as Davies and Downward indicate, there is ample scope for greater application of new industrial organisation theory in this field.

By contrast, some fields of tourism economics are relatively new, or have taken a rather different turn. One of these concerns the measurement of economic impacts of tourism, for example the impacts of additional tourism into an economy, policy changes, such as in taxation or promotion, which influences tourism flows, or events or crises which affect tourism. Until about a decade ago, the prevailing approach to impact measurement was one using inputoutput multipliers - this approach normally produced an estimate of the impact on output which was a multiple, often about two, or the original change in tourism spending. Recently there has been a trend towards the use of computable general equilibrium (CGE) models. These are models which try to capture the overall structure of the economy, and reflect the interaction of markets and the presence of resource constraints. These models are now used extensively in the USA, the UK and Australia to assess the economic impacts of policy, for example on GDP, employment, tax receipts and industry structure. While their use in other areas, such as tax policy, trade policy and investment evaluation, is commonplace, they have only recently been used to explore tourism policy questions. Typically, these models come out with much smaller impacts on the key economic variables than do the input-output-based approaches, because they allow for crowdingout effects in other parts of the economy. They are now being used to explore a whole range of tourism policy questions, such as the impacts of taxes and promotion, the impacts of crises and growth in tourism flows-these are covered in Blake, Gillham and Sinclair. These models can also be used to analyse the impacts of special events, as Dwyer, Forsyth and Spurr show.

Significantly, these models give very different perspectives on impacts of tourism changes from those generated by the earlier techniques, which are still in extensive use. Another aspect of tourism economics which has been given more attention of late has been international trade in tourism. Tourism is a major traded service, and for many countries, it represents the largest single export and import. Thus there is a new emphasis on looking at tourism as a traded service. This is reflected in the analysis of tourism competitiveness, and in the use of competitiveness and other variables to explain the patterns of trade in tourism (Sahli). Exposure to trade in turn has implications for the structure of the tourism industry, and Fletcher and Westlake show how globalisation is impacting on the industry. Part One addresses tourism demand and modelling issues. One of the aspects of tourism economics which attracts consistent interest is forecasting of demand. There are good reasons for this. The tourism product is perishable, but many of the costs incurred in providing for tourists are sunk. Thus there are substantial benefits from getting forecasts right. To do this, the demand function needs to be understood.

A good deal of interest surrounds demand elasticity estimates, such as estimates of price, cross-price and income elasticities. This is so for at least two reasons. Good elasticity estimates enable good demand forecasts. Second, much policy analysis relies on elasticity estimates. To estimate the impact of tax increases on tourism, or the effects of promotion on inbound tourism, a fall in air fares as a result of more competition from low cost carriers, or the impact of changes in competitiveness, it is necessary to have a good handle on the relevant elasticities. Papatheodoru examines the micro foundations of tourism demand. It is with knowledge of these that we are able to derive accurate specifications of demand to test econometrically. Lim pays attention to the specification and testing of demand models. It is evident in the studies which she reviews that there have been significant improvements in modelling of demand, though best practice is not universal. Song and Turner recognise the econometric issues involved in tourism demand forecasting, but also the relevance of aspects which are less easily captured, such as industry assessments.

\section{Literature review}

The activity of tourism creates impacts and consequences; we cannot prevent these, but need to plan and manage to minimize the negative impacts and accentuate the positive impacts of tourism. These impacts occur because tourism, both international and domestic, brings about an intermingling of people from diverse social and cultural backgrounds, and also a considerable spatial redistribution of spending power, which has a significant impact on the economy of the destination. Early work on the impact of tourism on destinations focused primarily on economic aspects. This was not only because such impacts are more readily quantifiable and measurable, but also there was a pervading climate of optimism that these studies would show that tourism was of net economic benefit to host destinations.

In many cases, this was indeed true. Yet tourism, by its very nature, is attracted to unique and fragile environments and societies and it became apparent that in some cases the economic benefits of tourism may be offset by adverse and previously unmeasured environmental and social consequences. The benefits and costs of tourism accrue to two quite distinct groups of people. On the one hand, the visitors themselves receive benefits and incur costs in taking holidays. On the other hand, the resident populations of the host region benefit from tourism (not only financially) but at the same time incur costs of various types. Because it is not possible to deal adequately with both aspects within the limited scope of this single chapter, attention will be devoted to the positive and negative effects of tourism from the point of view of the host country or region. The general issues central to any discussion of the positive and negative impacts of tourism must include notions of carrying capacity and also of how impacts can be assessed. Carrying capacity is a relatively straightforward conceptin simple terms it refers to a point beyond which further levels of visitation or development would lead to an unacceptable deterioration in the physical environment and of the visitor's experience. ${ }^{6,7,8}$ Commentators point out that operationalising capacity is difficult. Buckley, ${ }^{9}$ for example, mounts a scathing attack on the concept and its utility, stating that carrying capacity is 'ultimately meaningless.' This is echoed by McCool and Lime (2001) who state that 'the concept of a tourism and recreation carrying capacity maintains an illusion of control when it is a seductive fiction, a social trap, or policy myth.' Yet, despite this debate and discussion in the literature, the basic conceptual framework of carrying capacity remains the same, ${ }^{10}$ and however it is approached, there is no doubt that any consideration of the impact of tourism must recognise the pivotal role that carrying capacity plays by intervening in the relationship between visitor and resource. 
Effectively, the impact made by tourism depends on both the volume and profile characteristics of the tourists (including their length of stay, activity, mode of transport, and travel arrangement). In this respect, a number of authors have attempted to classify tourists according to their impact on the destinations. ${ }^{11}$ The character of the resource (including its natural features, level of development, political and social structure) is equally important because it determines the degree of its robustness to tourism and tourism development. ${ }^{12} \mathrm{~A}$ range of variables, therefore, needs to be taken into account in any determination of the impact of tourism. Yet determining such impacts also raises a number of issues. In economics, impact methodology has a long pedigree, but the measurement of environmental and social impacts has not progressed anywhere near as far. Indeed, in all forms of impact analysis, it is important to distinguish tourism-induced events from other agents of change, ensure that secondary and tertiary effects are considered, and have a view as to what the situation was before tourism intervened. All of these points are problematic and the tendency is therefore to simplify and narrow the scope of investigation to 'contain' the research into a manageable outcome. ${ }^{12}$ In part, the difficulty of quantifying the environmental and social impacts of tourism has delayed the development of impact methodologies. But the rising tide of environmentalism has caught up with tourism and has lent support to the view that in some cases the economic benefits of tourism are more than outweighed by the environmental and social costs of tourism. Concepts such as 'sustainable tourism development' and 'the responsible consumption of tourism' are seen by many as the answer, along with the enhanced planning and management of tourism. These issues are discussed later in this chapter. Nonetheless, the issue of management is closely related to the notion of carrying capacity because a destination can be 'managed' to take any number of visitors. Simply 'hardening' the environment and managing the visitor can accommodate large volumes without an unacceptable decline in the environment or the experience.

McCool \& Lime ${ }^{8}$ reconceptualise carrying capacity along these lines, suggesting that managers should be looking at the particular conditions that are desired or appropriate at a destination to support recreation and tourism activity-'sustaining these conditions is at the heart of concerns over impacts, saturation and carrying capacities.' The question must therefore be asked, managing and sustaining these conditions for whom? In pluralistic societies, the conflicts and tensions between the stakeholders in tourism-tourists, developers, planners, environmentalists, and communities-will in the end determine levels of tourist development. Butler ${ }^{13}$ then raises the question as to how we judge the notion of the 'satisfaction' of these various stakeholders as one of the key research questions for sustainable tourism. After all, tourism takes place within political and social contexts of power, relationships, and governance. It is, however, heartening that the result of this discussion is a continued pressure for sustainable tourism amongst the various groups in society and that this is changing the perceived balance between the positive and negative effects of tourism. This balance has also been influenced by the events of the early years of the twenty-first century including the terrorist attacks on New York and the bombings in Bali. It could be said that these 'shocks' to the tourism system have acted to reduce the impacts of tourism in some parts of the world because levels of international travel have reduced and tourists have switched to domestic travel or opted for destinations that are perceived as 'safe.'

\section{Defining tourism}

Etymologically, the word tour is derived from the Latin 'tornare' and the Greek 'tornos,' meaning 'a lathe or circle; the movement around a central point or axis.' This meaning changed in modern English to represent 'one's turn.' The suffix-ism is defined as 'an action or process; typical behavior or quality' whereas the suffix-ist denotes one that performs a given action. When the word tour and the suffixesism and-ist are combined, they suggest the action of movement around a circle. One can argue that a circle represents a starting point, which ultimately returns back to its beginning. Therefore, like a circle, a tour represents a journey that it is a round trip, i.e., the act of leaving and then returning to the original starting point, and therefore, one who takes such a journey can be called a tourist. There is some disagreement as when the word tourist first appeared in print. Smith ${ }^{14}$ suggests that "Samuel Pegge reported the use of "tourist" as a new word for traveller c. 1800; England's Sporting Magazine introduced the word "tourism" in 1911.' Feifer ${ }^{15}$ proposes that the word tourist 'was coined by Stendhal in the early nineteenth-century [1838].' Mieczkowski ${ }^{16}$ states that 'The first definition of tourists appears in the Dictionnare universal du XIX siecle in 1876,' defining tourists as 'persons who travel out of curiosity and idleness.' Kaul ${ }^{17}$ argues that even though the word tourist is of comparatively recent origin, nevertheless invaders were commonly referred to as tourists in the hope that one day they would leave.

In addition, Kaul points out that: In the 17th and early 18th centuries, the English, the Germans and others, traveling on a grand tour of the continent, came to be known as 'tourists.' In 1824, Scott, in San Roman's stated thus, 'it provoked the pencil of every passing tourist.' Leiper ${ }^{18}$ relates that the word tourism appears to have first been used in England to describe young male British aristocrats who were being educated for careers in politics, government, and diplomatic service. In order to round out their studies, they embarked on a customary three year grand tour of the European continent, returning home only after their cultural education was indeed completed. According to Inskeep, ${ }^{19}$ the first guidebook for this type of travel was Thomas Nugent's The Grand Tour, published in 1778. Far from the traveler of 1778, today's tourist tends to connote a singularly negative image, one who is a bargain hunter, who travels en masse, and according to Eliot (1974), is one who is sought out for his cash, but despised for his ignorance of culture. In addition, tourism has been variously defined (or refined) by governments and academics to relate to such fields as economics, sociology, cultural anthropology, and geography. Economists are concerned with tourism's contributions to the economy and economic development of a destination area, and focus on supply/demand, foreign exchange and balance of payments, employment, and other monetary factors. Sociologists and cultural anthropologists study the travel behaviour of individuals and groups of people, and focus on the customs, habits, traditions, and lifestyles of both hosts and guests. Geographers are concerned with the spatial aspects of tourism, and study travel flows and locations, development dispersion, land use, and changes in the physical environment.

It is generally recognised that there are two different types of tourism definitions, each with its own rationale and intended usage. Burkart \& Medlick ${ }^{20}$ suggest that there are conceptual definitions that attempt to provide a theoretical framework in order to identify the essential characteristics of tourism, and what distinguishes it from similar, sometimes related, but different activity. Examples of such 
a conceptual definition would include that proposed by Jafari ${ }^{21}$ who states that 'tourism is a study of man away from his usual habitat, of the industry which responds to his needs, and of the impacts that both he and the industry have on the host socio-cultural, economic, and physical environments.' In addition, Mathieson \& Wall ${ }^{12}$ conclude that 'Tourism is the temporary movement of people to destinations outside their normal places of work and residence, the activities undertaken during their stay in those destinations, and the facilities created to cater to their needs.' There are also technical definitions that provide tourism information for statistical or legislative purposes. The various technical definitions of tourism provide meaning or clarification that can be applied in both international and domestic settings. This later approach, technical definitions, can be seen in the actions taken to help standardize comparative international tourism data collection. Finally, Leiper ${ }^{18}$ postulated that there are three approaches in defining tourism: economic, technical, and holistic. Economic definitions view tourism as both a business and an industry. Technical definitions identify the tourist in order to provide a common basis by which to collect data. Holistic definitions attempt to include the entire essence of the subject. It is extremely difficult to define precisely the words tourist and tourism because these terms have different meanings to different people, and no universal definition has yet been adopted. For example, Webster's New University Dictionary defines tourism as 'traveling for pleasure; the business of providing tours and services for tourists,' and a tourist as 'one who travels for pleasure.' These terms are inadequate synonyms for travel, and their use as such adds further confusion when the field of travel is variously referred to as the travel industry, the tourism industry, the hospitality industry, and most recently, the visitor industry. Why is so much attention given to these definitions? According to Gee et al.,"22 the concern is from both an academic and a practical perspective. 'First, travel research requires a standard definition in order to establish parameters for research content, and second, without standard definitions, there can be no agreement on the measurement of tourism as an economic activity or its impact on the local, state, national or world economy.'

Therefore, comparable data are necessary requisites, and identical criteria must be used in order to obtain such data. For example, in North America, the U.S. Census Bureau and the U.S. Travel Data Center's annual travel statistics consider only those trips taken that are 100 miles or more (one-way) away from home. However, Waters ${ }^{23}$ argued that this criteria is unreasonably high, and proposed instead in his annual compendium on travel that similar to the U.S. National Tourism Resources Review Commission's guidelines (1973), distances of 50 miles or more are a more realistic criteria. On the other hand, the Canadian government specifies that a tourist is one who travels at least 25 miles outside his community. Therefore, each of these four annual data sets is quite different, and which (if any) contains the most accurate measurement of tourism activity? The United Nations (UN) was so concerned about the impossible task of compiling comparative data on international tourism that they convened a Conference on Trade and Development, which issued guidelines for tourism statistics (UNCTAD Secretariat, 1971). The ensuing report suggested that the functions of a comprehensive system of national tourism statistics could serve:

a) To measure from the demand side the volume and pattern of foreign (and domestic) tourism in the country (as well as outgoing tourism), b) To provide information about the supply of accommodation and other facilities used by tourists, and

c) To permit an assessment to be made of the impact of tourism on the balance of payments and on the economy in general.

Therefore, accurate statistical measurement of travel and tourism is important in order to assess its direct, indirect, and induced economic impacts; to assist in the planning and development of new tourist facilities and resources; to determine current visitor patterns and help formulate marketing and promotional strategies, and to identify changes in tourist flows, patterns, and preferences.

\section{Political effects}

Whereas the virtues of international tourism have been extolled as a major force for peace and understanding between nations, ${ }^{24-27}$ the reality is often far removed from this utopian image. Long-haul travel between developed and developing countries is increasing annually and is bringing into direct contact with each other people from widely different backgrounds and with very contrasting lifestyles and levels of income. Where these disparities are very great, the political as well as the sociocultural consequences may be severe. In extreme cases international tourism has imposed a form of 'neo-colonial' type development on emerging nations. ${ }^{28,29}$ Quite simply, this neo-colonialism takes power from the local and regional levels and concentrates it into the hands of multinational companies. These companies will negotiate only at the national level and expect any 'problems' to be solved by national governments, otherwise investment will be withdrawn. At the operational level, the higher paid, more 'respectable' posts in hotels and other establishments are sometimes occupied by expatriates who possess the necessary expertise and experience. Although the lower paid, more menial jobs are frequently reserved for the indigenous population, it is possible that such apparent discrimination can foster resentment and can sour international relationships. In extreme cases such development can even inhibit the growth of a national consciousness in a newly dependent country. Domestic tourism, on the other hand, can act as an integrating force strengthening national sentiment. Peoples in outlying areas are traditionally more preoccupied with local village affairs and, in consequence, sometimes prove easy prey to separatist agitators. If, by travel to other parts of the same country, such people can begin to experience pride in their national heritage, a sense of national unity may help to prevent regional fragmentation.

In the more developed countries, visits to national historical monuments, stately homes, and ancient battlefields form a significant motivation for domestic travel, and similar developments are already taking place in other parts of the world. In many developing countries, students and groups of schoolchildren travel to other regions of their homelands, and such movements of people can do much in the long run to strengthen the political unity of a country. Provided that the individual characteristics and identities of the various regions are not submerged and lost, such travel can benefit both tourists and residents alike. Unfortunately, contact between peoples of different backgrounds is not always beneficial and may in some cases generate additional cultural, social, and moral stresses. Although the mixing of people from different regions of a country can produce a better understanding of each other's way of life and a better appreciation of problems specific to particular regions, it can at the same time create misunderstandings and even distrust. 
So far political scientists have contributed relatively little to the analysis of tourism, and most of the work in this field has been concerned with the situation in particular countries. Noteworthy exceptions include books by Hall, ${ }^{28}$ Hall \& Jenkins, ${ }^{29}$ and $\mathrm{Kerr}^{30}$ and a paper by Mathews \& Richter. ${ }^{31}$ The books provide a framework for the examination of tourism and politics/policy making, whereas the paper by Mathews and Richter reviews the efforts made by political scientists to apply their special disciplines to the study of tourism. The authors examine first the ways in which many important aspects of tourism involve some of the central concepts of political science and, second, the contribution that political science can make to the study of tourism. Two major issues in tourism can be addressed by political scientists.

1. A fuller understanding of the human impact of tourism on destination areas can be achieved only by a much greater integration of the work of political scientists with specialists in other disciplines and with tourism practitioners

2. Knowledge of the impact of tourism on many aspects of human life and organization can be improved if more political scientists are willing to use their expertise to study tourism as an independent variable affecting areas of concern in public administration, comparative politics, political theory, international relations, and national politics. ${ }^{32}$

Specific work is needed in a variety of areas but particularly welcome would be:

a) Studies examining the influence of tourism on the roots of power in communities and the implications for community-based investment and the integration of tourism into the community. A major contribution here would be in terms of examining the many political interests involved in the development of tourism and the role of conflict resolution and consensus models. ${ }^{33}$

b) Work examining the stage of destination life cycle at which community involvement is most appropriate, and the stages at which communities are most vulnerable to external political and commercial decision making.

c) Further examination of policy impact analysis within a tourism and event context. ${ }^{34}$

\section{Sociocultural effects}

Although political effects are influential, it is difficult to disentangle them from the social and cultural effects of tourism. For example, Tsartas ${ }^{35}$ examines the influence of local social structures, particularly the family, on both tourism development and policy in the Greek islands and coastal areas. These social influences on policy and planning have led to unplanned and rapid tourism development, partly driven by the pressures of mass tourism and the downgrading of agriculture as an economic sector. Wide cultural differences occur between different countries and sometimes between different regions within the same country. Indeed the existence of such differences may be one of the principal stimulants of a tourism industry. In some developing countries such traditional cultural behaviour patterns of particular groups of people form one focus of the tourism industry. ${ }^{36}$ Sometimes, however, differences in physical appearance and, perhaps more importantly, differences in cultural behaviour between visitors and residents, are so great that mutual understanding is replaced by antipathy. The problem is exacerbated because tourists are, by definition, strangers in the destination. Their dress codes and patterns of behaviour are different to the residents and, often, different from those that the tourist would display at home; inhibitions are shed and the consequent problems of prostitution, drugs, gambling, and sometimes vandalism ensue. As strangers, tourists are also vulnerable and fall victim to robbery and crimes perpetrated by the local community who may see these activities as a way to 'redress the balance.' Lindberg, Andersson, and Dellaert ${ }^{37}$ chart the social gains and losses to residential populations as a result of tourism stating that the attitudes of residents are heterogeneous, with this very diversity creating a challenge to decision makers who try to reach consensus. This comes down to recognising that the values of residents, rather than straight demographics, may explain antecedents of opinions on tourism..$^{38}$

When the cultural distinctions between the residents and tourists from more prosperous countries and regions are strongly marked, local culture and customs may be exploited to satisfy the visitor, sometimes at the expense of local pride and dignity. Here the issue of staged authenticity is an important one where the host destination is able to convince tourists that festivals and activities in the "front region' of the destination (e.g., public areas such as hotel lobbies or restaurants are authentic and thus they protect the real 'back region', i.e., residents' homes and areas where life continues. ${ }^{39,40}$ Tourists are increasingly motivated by a quest for authenticity, and one of the problems of 'alternative tourism' is that the tourists are encouraged to penetrate the 'back region.' With good management and planning, however, tourism can provide an impetus for the preservation of ancient cultures, but too often the local way of life degenerates into a commercially organized effigy of its former self. The traditional dances and the skilled craftwork give way to cheap imitations to satisfy the needs of the visitor and to obtain money with the least possible effort. Here, Medina ${ }^{41}$ recounts that Mayan indigenous peoples even access new channels (such as archaeologists) to research and revive their traditional practices. In some cases this is merely an initial response and, later, tourism can stimulate high quality revivals of crafts in particular. Nonetheless, there is a constant tension in countries wishing to be part of the global tourism movement but also to retain their cultural authenticity Brunet et al. ${ }^{42}$ In primitive and isolated areas, the arrival of too many visitors can even cause local people to leave their settlements and move to new areas where they can remain undisturbed. To combat this in vulnerable areas such as North American Indian reservations, 'governing rules' for visitors have been formulated. In more developed areas, in extreme cases, tourism has disrupted completely the way of life of the local people. The institution of the national park system in some parts of Africa, although justifiable on the grounds of wildlife conservation and tourism, has in some cases seriously affected the hunting and nomadic existence of the local people. The problem is not confined, however, to developing countries. In Canada, for example, the creation of parks of outdoor recreation and domestic tourism at Forillon and Gros Morne necessitated the eviction of previous residents and in consequence aroused considerable local opposition. Insufficient research has been carried out so far to disentangle the social and cultural side effects of tourism development. Where the cultural and socioeconomic backgrounds of the tourists are very different from those of the local population, the results of their intermingling may be favourable but it can be explosive. The so-called demonstration effect of prosperity amid poverty may create a desire among local people to work harder or to achieve higher levels of education in order to emulate the way of life of the tourists. 
On the other hand, in many cases the inability of the local people to achieve the same level of affluence may create a sense of deprivation and frustration, which may find an outlet in hostility and even aggression. The merit of social intercourse between tourists and the indigenous population as a means toward fostering better understanding and goodwill between nations has been extolled as a major social benefit obtained from tourism. Although this is true in many cases, particularly in those countries where tourists are still comparatively rare, it is certainly not true in many countries where tourists' tastes and habits have proved offensive to particular sectors of the local population. Because of factors such as these, some writers have rejected the term 'demonstration effect' and substituted the term 'confrontation effect.' Perhaps the most significant and one of the least desirable by-products of this confrontation is the effect on the moral standards of the local people. In extreme cases, crime, prostitution, gambling, and drug traffic may be imported into the holiday areas from other regions. Many of the social conventions and constraints imposed on tourists in their home areas are absent when they visit another region, and in consequence their moral behaviour can deteriorate without undue censure. As a result, many local people find that by catering to the several needs of their visitors they themselves can achieve a relatively high level of prosperity. Although the credit or blame for developments such as red light districts can be attributed more to the growth of international tourism than to an increase in domestic tourism, the latter must bear its share of responsibility. A critical issue here is the form of contact between host and guest. In the 'enclave' tourism model, so berated by proponents of 'alternative forms of tourism,' contacts are controlled and minimal, mainly confined to 'culture brokers' who speak the language of both host and guest and who understand both cultures. It is when the tourist penetrates into the daily lives and homes of the hosts, the back region, that real exposure of cultural and social differences between the two groups emerge, and problems may occur.

Tourists have been blamed for assisting the spread of sexually transmitted diseases and AIDS in many countries, but their contribution is probably very small in relation to the part played by the local population. Indeed, visitors themselves do not always emerge unscathed from their interaction with the local community. ${ }^{43-45}$ Poor hygienic conditions in many tourist resorts create suitable conditions for the spread of various intestinal diseases, typhoid, cholera, and hepatitis. Lack of forethought and ignorance result in cases of severe sunstroke and skin cancer. Inappropriate precautions result in infection by the AIDS virus, which already affects a significant percentage of the population of some countries in Africa. Governments, tour operators, airlines, and resort operators have a duty to visitors and residents alike to provide adequate information to ensure that these risks are known and minimized. Many of the other sociocultural problems associated with tourism are related to the degree of intensity of tourism development. Although difficult to measure, there is a relationship between tourism density and the growth of local resentment toward tourism. The flow of tourists into a region increases the densities at which people live and overcrowds the facilities that tourists share with the local population. Overcrowding reduces the value of the holiday experience and creates additional strain for the resident population. In extreme cases local people may be debarred from enjoying the natural facilities of their own country or region. Along part of the Mediterranean, for example, almost half of the coastline has been acquired by hotels for the sole use of their visitors, and in consequence the local public is denied easy access.

\section{Sustainable development and tourism}

We have tried to review the key elements of the positive and negative impacts of tourism. As mentioned earlier, it is only in recent years that the negative 'downstream' effects of tourism on the environments, societies, and vulnerable economies have been set more fully against the tangible economic gains. Add to this the rise of environmentalism and 'green' consciousness in the mid to late 1980 s, and the stage was set for a reassessment of the role and value of tourism. In part, this is also a reflection of the growing maturity of both the tourist as consumer and the tourism sector itself. In the early decades of mass tourism, short term perspectives prevailed as the industry and public agencies attempted to cope with burgeoning demand. In the 1980s, 1990s, and early years of the twenty-first century, growth rates slowed and tourists began questioning some of the excesses of tourism development. In response, longer planning horizons are being considered and new forms of tourism advocated as industry and governments slipstream behind public opinion and media attention given to these issues. One of the most valuable results of this reassessment has been the belated discovery of the relevance of the sustainable development concept to tourism..$^{46-49}$ As with many service industries, some of the most important ideas and innovations come from outside the industry or the subject area. The concept of sustainable development has a long pedigree in the field of resource management and has, at last, become an acceptable term in tourism. It has also become a debated term with definitional arguments over its meaning and operationalisation, particularly as the meaning of sustainability increasingly implies a 'triple bottom line' approach. ${ }^{50}$

The oft quoted Brundtland Report defines sustainability simply as 'meeting the needs of the present without compromising the ability of future generations to meet their own needs'. ${ }^{51}$ The concept of sustainability is central to the reassessment of the role of tourism in society. It demands a long-term view of economic activity, questions the imperative of continued economic growth, and ensures that consumption of tourism does not exceed the ability of a host destination to provide for future tourists. In other words, it represents a tradeoff between present and future needs. In the past, sustainability has been a low priority compared with the short-term drive for profitability and growth, but, with pressure growing for a more responsible tourism industry, it is difficult to see how such short-term views on consumption can continue. Indeed, destination 'regulations' have been developed in some areas, and already the bandwagon for sustainable development and responsible consumption is rolling. This is evidenced by a number of initiatives:

a) Public agencies are issuing guidelines for the ethical consumption of tourism (see, for example, the WTO's global code of ethics for tourism)

b) Industry sector organizations have developed sustainable auditing procedures for destinations.

c) Pressure groups and professional societies have devised codes of conduct for visitors and travelers (see, for example, the Audobon Society's 'travel ethic' and the Sierra Club's 'wilderness manners').

d) The private sector is developing responsible tourism policies for the operation of their companies (a major collective project here is the 'Tour Operator's Initiative for Sustainable Tourism Development' representing 25 companies worldwide; see also individual companies. 
e) Tourism consumer groups are growing in number and influence ${ }^{52}$ and guides to responsible tourism are increasingly available. ${ }^{53}$

f) Sustainable tourism is becoming integral to tourism curricula. ${ }^{54}$

As a philosophical stance or a way of thinking, it is difficult to disagree with the concept of sustainable tourism development and responsible consumption of tourism. But a little knowledge is a dangerous thing and some commentators have oversimplified the complex relationship between the consumption and development of tourism resources. This is particularly true of the so-called alternative tourism movement, which is lauded by some as a solution to the ills of mass tourism. Indeed, the tenor of much of the writing about alternative tourism is that any alternative tourism scheme is good, whereas all mass tourism is bad, although this is rightly refuted by Jafari. ${ }^{55}$ Butler $^{13}$ provides a useful characterization of the two extremes, whereas Wheeler ${ }^{56}$ provides telling criticism of alternative tourism. Others too warn of the ecotourism bandwagon; Beaumont ${ }^{57}$ is concerned that it preaches its values to the converted, whereas Ascot et al. ${ }^{58}$ classify deep and shallow ecotourism on the basis of commitment of the visitor. There is, of course, a case for alternative tourism, but only as another form of tourism in the spectrum. It can never be an alternative to masstourism, nor can it solve all the problems of tourism. ${ }^{59}$ Cohen's ${ }^{60}$ criticism is telling. He sees forms of sustainable tourism as 'green washing,' misrepresenting the concept and using it to gain access to take over the control of natural sites or cultural practices. He also warns of issues of equity in terms of using sustainability as an instrument of power in the restriction of visitation to key sites. A variety of issues emerge from these trends. It is important to disseminate cases of good practice in sustainable tourism, and to draw out generalities from these cases. In this way, responsible behaviour may pervade the provision and consumption of tourism and displace the more extreme calls for 'politically correct' tourism development. It must be recognised that the relationship of economics to environmental and social issues and policies in tourism is a complex one. ${ }^{61}$ Often economic policy is determined at the regional or national level, yet the impact of that policy is felt at the local level on environments and societies. ${ }^{62} \mathrm{TeO}^{63}$ observes that globalisation has heightened the imperative for sustainable tourism as global process impact on tourism at the local level and are then moderated by a range of processes and power relationships that determine the success or failure of sustainable tourism.

Good models of community participation and planning in tourism are increasingly available, ${ }^{64}$ and in particular the notion of destination 'visioning ' is growing in acceptance as a means of communities taking control of their tourism futures. ${ }^{64-68}$ But it must also be recognised that tourism takes place in many different social and political contexts and what works in one place may need adaptation for another. From this point of view, $\mathrm{Go}^{69}$ is less optimistic that there has been real progress in converting the good intentions of sustainable tourism into practice. This also applies to the borrowing of concepts and techniques from other subject areas and industries.

Nevertheless, tourism has much to learn from others. In particular, techniques of environmental management, visitor planning and management, and studies of visitor/environment relationships are well developed in the recreation literature, and are just as applicable to tourism. ${ }^{70}$ In particular, recreational managers are much more advanced in their use of the notion of 'capacity' than are tourism planners, ${ }^{8,71}$ although such mechanistic planning techniques are now being questioned. ${ }^{34}$ Perhaps the central issues emerging from this section are the gradual shift from short-term to longer-term thinking and planning in tourism; it is no longer acceptable for the industry to exploit and 'use up' destinations and then move on ${ }^{72}$ In addition there is an urgent need for tourism to sharpen up its terminology (e.g., alternative? responsible? soft, appropriate tourism?), to think clearly about the implications of sustainable/responsible initiatives, and to develop a code of business ethics.

\section{Tourism statistics}

The principal difficulty in measuring the extent of tourism demand is the basic incomparability of tourism statistics. Such incomparability exists not only when attempting to compare data from various nations, but also creates problems when regions, provinces, states, or cities within a country attempt to compare with one another data on tourism demand. At the international level, there are a number of reasons for this incomparability. The definitions of a tourist and a visitor vary, especially at frontiers where statistics are collected. Not all countries have adopted the UN Statistical Commission's definitions, whereas others use their own definitions. Even when the UN definitions are used, data collection methods vary widely so that some countries may not gather information on the purpose of a visit or whether or not the visitor will be (or has been) remunerated. In addition, although most countries gather statistical data at their frontiers, others rely on information provided by hotel registrations. In this case, even though the same definitions may be used, the two data sets are not comparable. Some countries do not even count the arrivals of foreign nationals from bordering countries, especially if there is a unique or special relationship between the countries. Often, in some world nations visitors who are travelling for business or other similar purposes are not regarded as tourists, and therefore they are not recorded as such. In addition, students who spend most of the academic year studying abroad in foreign countries are also often overlooked when compiling statistical data. Excursionists and other day visitors are included in the statistical data of some countries, but are excluded in others. Special situation visitors such as cruise ship passengers are often not counted in some countries because they are considered to be transients. Flight crews and other visitors in transit are often treated likewise. Frechtling ${ }^{73}$ suggests that of the 184 nations in the world, 166 report tourism data to the WTO each year, and: [o]f these 166 countries, four do not have a measure of international visitors or tourists. Thirteen countries have no recent measure of international tourism receipts, and 46 do not estimate international travel expenditures. More than onehalf (84) have no measure of international departures, and two-thirds (113) do not count visitor nights in all accommodation establishments.

At the subnational level, similar situations also exist. For example, in the United States, there is no standard definition valid throughout the country. As a result, definitions of tourism vary from state to state. Gee, Makens, and Choy (1989) suggest that in Florida, 'a tourist is an out-of state resident who stays at least one night in the state for reasons other than necessary layover for transportation connections or for strictly business transactions.' In Alaska, 'a tourist is a nonresident traveling to Alaska for pleasure or culture and for no other purpose.' Massachusetts defines a tourist as 'a person, not on business, who stays away from home overnight.' For Arizona, 'a tourist is a nonresident traveller in the state, while a traveller is used to identify Arizona residents traveling within the state.' In Utah, 'a tourist will participate in some activity while in the state, while a traveller simply passes through on their way to another state.' 
Finally, in Nevada, 'tourists are residents of states other than Nevada who visit the state or stop somewhere in the state while en route through and without regard for trip purpose.' The confusion in terminology is by no means limited to the United States. A review of any of the statistics published by the WTO/UN points out the innumerable footnotes to the data indicating national variations, differences in data collection methodology, and significant diversity in terminology standards. Indeed, one of the important tasks of the WTO is to work systematically to improve and help develop definitions and classifications of tourism that are of worldwide application and that emphasize both clarity and simplicity in their application. Throughout Europe, Wöber ${ }^{74}$ suggests that 'unfortunately, city tourism office managers have very little influence on the local authorities who are usually responsible for conducting national and regional tourism research studies.' Although in 1995 the Federation of European Cities Tourist Offices (FECTO) attempted to establish a common database of primary city tourism statistics among their members, nonetheless it has proved unworkable because of the lack of uniform reporting and definitional differences.

\section{Measures of tourism}

In June 1991, 250 individuals representing 90 countries participated in a landmark meeting held at Ottawa, Canada, and cosponsored by the WTO and Tourism Canada. This meeting, The International Conference on Travel and Tourism Statistics ${ }^{75}$ had three primary aims:

a) Development of a uniform and integrated definition and classification system of tourism statistics,

b) Implementation of a strict methodology for determining the economic impact of tourism and the performance of various sectors of the industry, and

c) Establishment of both a means of dialogue between governments and the tourism industry and a coherent work program for collecting tourism statistics and information.

The Conference was successful in agreeing on approaches to standardize tourism terminology and industrial classifications, as well as indicators of market growth, economic impact, and overall industry development. All delegates to the Conference endorsed the concepts, measures, and definitions that were proposed in the resolutions that came out of the meetings. In 1993, the UN accepted the report of the WTO and adopted the recommendations of the UN Secretariat's Statistical Division pertaining to tourism statistics.

One of the principal findings that came out of the conference resolutions ${ }^{75}$ recommended that tourism be defined as: the activities of a person travelling to a place outside his or her usual environment for less than a specified period of time and whose main purpose of travel is other than the exercise of an activity remunerated from within the place visited. In addition, tourism was further defined as the activities of people travelling for leisure, business, and other purposes to places outside their usual environment and staying for no more than one consecutive year. Baron ${ }^{76-80}$ has compiled a helpful list of those WTO/ UN-adopted definitions as shown in The Ottawa Conference further recommended the development and implementation of a system of performance measures and indicators, which could help measure trends and provide forecasts for the industry as a whole, thereby maximizing tourism's economic contribution to national benefits. They recommended that the concept of satellite accounting systems that derive their principle aggregates and basic concepts from the
United Nations System of National Accounts be supported, and that all countries introduce such accounting systems into their analytic base for tourism data on an incremental basis.

\section{Tourism industry}

Interest in collaboration in tourism has arisen at a time of increasing environmental turbulence and operational complexity for organisations of all kinds. A variety of drivers are behind this trend, the majority being linked in some way to the wider issue of globalisation. There can be little doubt that the predominant force acting on the world's economic systems today is that of globalisation. The process of globalisation has broken down the barriers between economic systems and encouraged them to become progressively more integrated with one another. The result has been the emergence of what can increasingly be described only as a single, global economy. Globalisation has been, and continues to be, driven by an array of converging forces. Advances in information technology, communication methods, and distribution systems, along with continued economic growth in the developing world, have all contributed greatly. Likewise, policy changes in many countries around the world and the emergence of transnational corporations are also reinforcing the trend toward globalisation. In the specific context of tourism, Wahab \& Cooper $^{81}$ suggest that the continuing growth in demand for tourism, the expansion and diversification of travel motivations, and the enlarged expectations of tourists are all contributing to the increasing global presence and significance of tourism in the world economy. Heightened competition among an ever-increasing number of destinations and the gathering trend toward deregulation in many of the world's tourism industries are also contributing to a more globalised environment in which the business of tourism must be conducted. Deregulation is particularly apparent in passenger air transportation, in that the policy of 'liberalisation' has resulted in the emergence of numerous bilateral 'open skies' agreements between international airlines. This policy has undoubtedly contributed to the development of airline hubs and the emergence of 'collaborative' strategic alliances in recent years. ${ }^{82-85}$ More generally, globalisation is leading to an increasingly borderless and interdependent world, and this serves as the catalytic focus for much collaborative activity.

Given the enormous power and reach of globalisation as a driving force in the business environment, Kanter ${ }^{86}$ argues that the success criteria for tourism organisations in a globalised society are changing. Kanter ${ }^{86}$ suggests that in the future, tourism organisations will no longer be judged only on the quality of their concepts and competencies, but also on their connections. The notion of 'connections' relates to the organisation's collaborative networks, that is, the alliances and relationships that lever core capabilities, create value for customers, and remove boundaries. The benefits of obtaining 'added value' through the creation of integrated networks or alliances can be considerable. Drawing on Porter ${ }^{87}$ concept of the value chain, Ashkenas ${ }^{88}$ argue that in a globalised society, the value chain has come to represent the single most significant concept by which organisations and enterprises are linked together. By integrating the activities along their value chain, organisations can work together to create products and services that have more value combined than separately. The increasingly competitive nature of global markets suggests that cooperation between firms, especially among smaller players, will continue to expand. This collaborative imperative is of particular importance in tourism, where the value chain is central to the creation of products by intermediaries. In this instance, globalisation 
provides the environment for a new way of thinking in the tourism distribution channel, as individual tourism businesses, intermediaries, and tourists in a channel cease to be adversarial and move to a more relational mode of behaviour. ${ }^{89}$ Many collaborative initiatives have already begun to evolve among organisations seeking to serve the increasing growth in tourism demand worldwide. The most notable form of interorganisation collaboration, strategic alliances, offers organisations the flexibility they need to 'deal with globalisation, increased consolidation of economic power, the high cost of keeping up with constantly changing technologies and a highly competitive business environment ${ }^{9} .^{90-94}$ Participants in such alliances are able to share resources and risks in a relatively cost-efficient manner, thereby combining their strengths and enhancing their ability to achieve economies of scale. Tourism is beset by many outside pressures: world events; budget problems and mounting deficits; recession; the staggering need for funds to support education, health care, social needs, and crime prevention; and the maturing, competitive tourism marketplace. In this environment, a great effort has been devoted to legitimizing tourism as a key industry in today's service economy. In great measure, these efforts have been successful. But, is this 'success' really positive? Or has the 'industry' label actually hurt the cause that this designation is supposed to champion. To answer this question we need to define what an industry is, use this definition as a framework to look at tourism, and then consider the ramifications of the difference. ${ }^{95-104}$

\section{Conclusion}

There can be little doubt that it is becoming increasingly more difficult for organisations to survive in competitive isolation in tourism. As illustrated earlier, both the international airline and hotel industries are leading the way in the adoption of collaborative relational marketing approaches in tourism. While tourism intermediaries, tourist attractions, and tourism destinations are also beginning to implement collaborative relational marketing strategies of their own, international airlines and independent hotels demonstrate very clearly the benefits to be derived from collective strength in furthering their market positions and economic longevity. For most collaborative relational marketing strategies that have been implemented to date, however, the long-term outcomes remain unclear. This is simply because most of these strategies have yet to come fully to fruition. This chapter argues, however, that alternative approaches to existing 'competitive' marketing theory and practice are required for the future development of tourism. The foundations upon which existing competitive tourism marketing theory and practice are based are set to be tested and reconfigured in light of the drivers of collaboration discussed at the beginning of this chapter, and which are making such a profound impact on the world we live in and the ways in which we manage ourselves to accommodate them. The collaborative approaches discussed in this chapter perhaps offer a road map for the future longevity and prosperity of the global tourism industry. The literature on the sociocultural effects of tourism is quite extensive, although the majority of the contributions are concerned with specific cases in particular countries. Some of the more general contributions have been made by Dogan, ${ }^{105}$ Dann \& Cohen, ${ }^{106}$ Smith \& Brent, ${ }^{107}$ and Reisinger \& Turner. ${ }^{108}$ Dogan ${ }^{95}$ provides an interesting analysis in which he shows how the reactions of the host community to the influx of tourists and the changes that tourism brings has been quite diverse, ranging from an active resistance to the complete acceptance and even adoption of the tourists' culture patterns. He shows how the choice of strategies, deliberate or otherwise, to cope with the changes depends on both the nature of the sociocultural characteristics of the host community and the magnitude of the changes themselves. His conclusion is that even in the case of a previously homogenous community that adopts a particular response to tourism, the community will itself become diversified and groups will emerge within the community exhibiting very different responses to tourism developments. Dann and Cohen are concerned with the contribution that the discipline of sociology can make to the understanding of the tourism phenomenon. Here, different perspectives on tourism have been adopted by sociologists, and in consequence this has lead to the emergence of a variety of approaches. Dann and Cohen believe that ". .. some of the best work in tourism has been eclectic, linking elements of one perspective with those of another, rather than opting for an exclusive point of view.' Two major issues require the attention of sociologists:

a) There is a need for many more multidisciplinary studies where sociologists can contribute the insights of their discipline to the study of particular aspects of the tourism phenomenon or to the analysis of tourism in specific countries and regions. Here there is a clear need for work to examine the social-carrying capacity of destinations; work that must be closely linked to community-based models of tourism planning and the 'limits of acceptable change'. ${ }^{10}$ Mitchell \& Reid ${ }^{109}$ stress the need for research into mechanisms of community integration into the planning process. Indeed, although much is written on why community empowerment is important, there is much less written on how to do it.

b) The quantification of the socioeconomic costs and benefits of tourism requires the joint efforts of sociologists and economists. At present this work is being carried out almost entirely by economists, Leitner, ${ }^{110}$ who are not always in the best position to identify all of the phenomena requiring quantification or the appropriate weightings to apply to each. ${ }^{111-116}$

Planning for the resultant impact of tourism necessitates a careful definition of the respective responsibilities of the public and private sectors and communities. Planning should be designed to maximize the economic and social benefits of tourism to the resident population, ${ }^{117-119}$ whereas at the same time mitigating or preferably eliminating the adverse effects. In the past most of this type of planning has been remedial-it has taken place after much development has occurred. In the future, planners and communities must take a more proactive role in controlling the nature of such development in terms of stricter building and design regulations; controlled access to vulnerable sites and attractions; strict transport regulations, especially in core areas; and the use of entry fees, barriers, and designated routes for vehicles and pedestrians alike. Tourism creates both positive and negative effects in the destination country or region. Thoughtful policy making and planning can do much to minimize or even remove the negative effects. Tourism can be a very positive means of increasing the economic, social, cultural, and environmental life of a country. The major issue now is can politicians, planners and developers, and citizens rise to the challenge and create a truly responsible Sharpley, ${ }^{120}$ and thus acceptable, tourism industry, one which brings long-term benefits to residents and tourists alike without compromising the physical and cultural environment of the destination region.

\section{Acknowledgements}

None. 


\section{Conflict of interest}

The author declares that there is no conflict of interest.

\section{References}

1. Archer BH, Fletcher JE. Multiplier Analysis in Tourism: Cahiers $d u$ Tourisme. Centre Des Hautes Etudes Touristiques. Aix en Provence: University de Droit; 1991. 103 p.

2. Tosun C, Timothy DJ, Öztürk Y. Tourism Growth, National Development and Regional Inequality in Turkey. Journal of Sustainable Tourism. 2003;11(2 and 3):133-161.

3. Meis Scott. International Issues Forum: Response. Tourism Partnerships and Strategies: Merging Vision With New Realities. Proceedings of the 23rd Travel and Tourism. Minneapolis: Research Association Conference; 1992. $14-17 \mathrm{p}$.

4. McIntosh, Robert W, Charles R Goeldner, et al. Tourism Principles, Practices, Philosophies. 7th ed. New York: John Wiley \& Sons; 1995. $551 \mathrm{p}$.

5. Hawkins, Donald E, Brent Ritchie JR, editors. World Travel and Tourism Review: Indicators, Trends and Forecasts. Wallingford: CAB International; 1991. 243 p.

6. Getz D. Capacity to Absorb Tourism: Concepts and Applications for Strategic Planning. Annals of Tourism Research. 1983;10(2):239-263.

7. O’Reilly AM. Tourism Carrying Capacity. Tourism Management 1986;7(4):254-258.

8. McCool SF, Lime DW. Tourism Carrying Capacity: Tempting Fantasy or Useful Reality? Journal of Sustainable Tourism. 2001; 9(5):372-388.

9. Buckley R. An Ecological Perspective on Carrying Capacity. Annals of Tourism Research. 1999;26(3):705-708.

10. Saveriades A. Establishing the Social Tourism Carrying Capacity for the Tourist Resorts of the East Coast of the Republic of Cyprus. Tourism Management. 2000;21:147-156.

11. Smith V. Hosts and Guests: Anthropology of Tourism. Philadelphia: University of Pennsylvania Press; 1977. 352 p.

12. Mathieson A, Wall G. Tourism: Economic, Physical and Social Impacts. London: Longman; 1982. 208 p.

13. Butler R. Alternative Tourism: Pious Hope or Trojan Horse? Journal of Travel Research. 1990;28(3):40-45.

14. Smith, Stephen LJ. Tourism Analysis: A Handbook. London: Longman Scientific \& Technical; 1989. 322 p.

15. Feifer Maxine. Tourism in History: From Imperial Rome to the Present. New York: Stein and Day Publishers; 1985. 288 p.

16. Mieczkowski Zbigniew. World Trends in Tourism and Recreation. New York: Peter Lang Publishing; 1990. 370 p.

17. Kaul RN. The Dynamics of Tourism. New Delhi: Sterling Publishers Private Limited; 1985.711 p.

18. Leiper Neil. The Framework of Tourism: Towards a Definition of Tourism Annals of tourism Research. 1979;6(4):390-407.

19. Inskeep Edward. Tourism Planning: An Integrated and Sustainable Development Approach. New York: Van Nostrand Reinhold; 1991.528 p.

20. Burkart AJ, Medlik S. Tourism: Past, Present and Future. London: Heinemann; 1981. 354 p.

21. Jafari Jafar. Editor's Page. USA: Annals of Tourism Research; 1977.
22. Gee C, Makins C, Choy D. The Travel Industry. 3rd edition. New York: Van Nostrand Reinhold; 1997. 512 p.

23. Waters Somerset. Travel Industry World Yearbook: The Big Picture (annual). New York: Child and Waters; 1987. 152 p.

24. Manila Declaration on World Tourism. Madrid: World Tourism Organization; $1980.40 \mathrm{p}$

25. Tourism in the Age of Alliances, Mergers and Acquisitions. Madrid: the World Tourism Organization; 2002. 295 p.

26. Litvin SW. Tourism: The World's Peace Industry. Journal of Travel Research. 1988;37(1):63-66.

27. Leitner MJ. Promoting Peace Through Intergenerational Tourism. Tourism Recreation Research. 1999;24(1):53-56.

28. Hall CM. Tourism and Politics. Chichester: Wiley \& Sons; 1994. 238 p.

29. Hall CM, Jenkins JM. Tourism and Public Policy. London: Routledge; $1995.327 \mathrm{p}$.

30. Kerr WR. Tourism Public Policy and the Strategic Management of Failure. St. Louis: Elsevier; 2003. 312 p.

31. Mathews HG, Richter LK. Political Science and Tourism. Annals of Tourism Research. 1991;18(1):120-135.

32. Richter LK. Tourism Politics and Political Science: A Case of Not So Benign Neglect. Annals of Tourism Research. 1983;10(3): 313-335.

33. Jamal TB, Getz D. Collaboration Theory and Community Tourism Planning. Annals of Tourism Research.1995;22(1):186-204.

34. Whitford M. Event Public Policy Development in the Northern Subregional Organisation of Councils, Queensland Australia: Rhetoric or Realisation? Convention and Expo Summit 2003, School of Hotel and Tourism Management, Hong Kong Polytechnic University; 2003. 99 p.

35. Tsartas P. Tourism Development in Greek Insular and Coastal Areas: Sociocultural Changes and Crucial Policy Issues. Journal of Sustainable Tourism. 2003;11(2 and 3):116-132.

36. Butler R, Hinch T, editors. Tourism and Indigenous Peoples. London: International Thomson Business Press; 1996. 444 p.

37. Lindberg K, Andersson TD, Dellaert BGC. Tourism Development: Assessing Social Gains and Losses. Annals of Tourism Research. 2001;28(4):1010-1030.

38. Williams J, Lawson R. Community Issues and Resident Opinions of Tourism. Annals of Tourism Research. 2001;28(2):269-290.

39. McCannell D. Staged Authenticity: Arrangement of Social Space in Tourist Settings. American Journal of Sociology. 1973;79:586-603.

40. Ingles P. Welcome to My Village: Hosting Tourists in the Peruvian Amazon. Tourism Recreation Research. 2002;27(1):53-60.

41. Medina KL. Commoditizing Culture: Tourism and Maya Identity. Annals of Tourism Research. 2003;30(2):353-368.

42. Brunet S, Bauer J, De Lacy D, et al. Tourism Development in Bhutan: Tensions between Tradition and Modernity. Journal of Sustainable Tourism. 2001;9(3):243-263.

43. Petty R. Health Limits to Tourism Development. Tourism Management. 1989;10(3):209-212.

44. Cliff S, Grabowski P. Tourism and Health: Risks: Research and Responses. Tourism Recreation researches. 1997;20(3):55-61

45. Wilks J, Page SJ. Managing Tourist Health and Safety in the New Millennium. Amsterdam: Pergamon; 2003. 247 p. 
46. Pigram J. Sustainable Tourism Policy Considerations. Journal of Tourism Studies. 1990;2(3):2-9.

47. Farrell BH, Runyan D. Ecology and Tourism. Annals of Tourism Research. 1991;18(1):26-40.

48. Bramwell B, Lane B. Sustainable Tourism: Contributing to the Debates. Journal of Sustainable Tourism. 1999;7(1):1-5.

49. Holden A. Environment and Tourism. London: Routledge; 2000. 280 p.

50. Hardy AL, Beeton RJS, Pearson L. Sustainable Tourism: An Overview of the Concept and its Position in Relation to Conceptualisations of Tourism. Journal of Sustainable Tourism. 2002;10(6):475-496.

51. World Commission on Environment and Development. Our Common Future. New York: Oxford University Press; 1987. 300 p.

52. Botterill TD. A New Social Movement: Tourism Concern, The First Two Years. Leisure Studies. 1991;10(3):203-217.

53. Mann M. The Good Alternative Travel Guide: Exciting Holidays for Responsible Travelers. 2nd ed. Sterling: Earthscan Publications; 2002. $246 \mathrm{p}$.

54. Jurowski C. BEST Think Tanks and the Development of Curriculum Modules for Teaching Sustainability Development Principles. Journal of Sustainable Tourism. 2002;10(6):536-545.

55. Jafari J. The Scientification of Tourism. In Hosts and Guests Revisited: Tourism Issues of the 21st Century. In: Smith VL, Brent M, editors. New York: Cognizant; 2001. $462 \mathrm{p}$.

56. Wheeler B. Tourism's Troubled Times. Tourism Management. 1991;12(2):91-96.

57. Beaumont N. Ecotourism and the Conservation Ethic: Recruiting the Uninitiated or Preaching to the Converted? Journal of Sustainable Tourism. 2001;9(4):317-341.

58. Ascot TG, La Trobe HL, Howard SH. An Evaluation of Deep Ecotourism and Shallow Ecotourism. Journal of Sustainable Tourism. 1998;6(3):238253.

59. Duffy R. A Trip Too Far: Ecotourism, Politics and Exploitation. London: Earthscan Publications; 2002. 168-170 p.

60. Cohen E. Authenticity, Equity and Sustainability in Tourism. Journal of Sustainable Tourism. 2002;10(4):267-276.

61. Archer BH. Tourism Multipliers: The State of the Art. Cardiff: University of Wales Press; 1977. 85 p.

62. Hough JL, Sherpa MN. Bottom Up Versus Basic Needs. Ambio 1989;18(8):434-441.

63. Teo P. Striking a Balance for Sustainable Tourism: Implications of the Discourse on Globalisation. Journal of Sustainable Tourism. 2002;10(6):459-474

64. Richards G, Hall D. Tourism and Sustainable Community Development. London: Routledge; 2000. 320 p.

65. Murphy P. Tourism, A Community Approach. London: Routledge; 1985. 200 p.

66. Haywood KM. Responsible and Responsive Tourism Planning in the Community. Tourism Management. 1988;9(2):105-118.

67. Ritchie JRB. Crafting a Value-Driven Vision for a National Tourism Treasure. Tourism Management. 1999;20:273-282.

68. Ruhanen L, Cooper C. The Use of Strategic Visioning to Enhance Local Tourism Planning in Periphery Communities: The Tweed Shire, Australia. Taking Tourism to the Limits Conference. New Zealand: University of
Waikato; 2003. 290 p.

69. Go JTG. Assessing Progress of Tourism Sustainability. Annals of Tourism Research. 2001;28(3):817-820.

70. Cooper CP. The Technique of Interpretation. In Managing Tourism. Medlik S, editor. Oxford: Butterworth-Heinemann; 1991. 526-534 p.

71. Barkham JP. Recreational Carrying Capacity. Area. 1978;5(3):218-222.

72. Go FM, Appelman J. Achieving Global Competitiveness in SMEs by Building Trust in Interfirm Alliances. In: Wahab S, Cooper C, editor. Tourism in the Age of Globalisation. London: Routledge; 2001. 183-197 p.

73. Frechtling Douglas C. International Issues Forum: World Marketing and Economic Research Priorities for Tourism. Tourism Partnerships and Strategies: Merging Vision with New Realities. Minneapolis: Proceedings of the 23rd Travel and Tourism Research Association Conference; 1992.14-17 p .

74. Wöber Karl. Standardizing City Tourism Studies. Annals of Tourism Research. 2000;27(1):51-68.

75. International Conference on Travel and Tourism Statistics: Ottawa (Canada): 24-28 June 1991 Resolutions. Madrid: World Tourism Organization; 1991. $111 \mathrm{p}$

76. Gray B. Conditions Facilitating Interorganizational Collaboration. Human Relations. 1985;38(10):911-936.

77. Grönroos C. Defining Marketing: A Market-Orientated Approach European Journal of Marketing. 1989;23(1):52-60.

78. Hanlon P. Global Airlines: Competition in a Transnational Industry. 2nd ed. Oxford: Butterworth-Heinemann; 1999. 296 p.

79. Hardy AL, Beeton RJS. Sustainable Tourism or Maintainable Tourism: Managing Resources for More Than Average Outcomes. Journal of Sustainable Tourism. 2001;9(3):168-192.

80. Huxham C. Pursuing Collaborative Advantage. Journal of the Operational Research Society. 1993;44(6):599-611.

81. Wahab S, Cooper C. Tourism in the Age of Globalisation. London: Routledge; 2001. 345 p.

82. Helfert G, Ritter T, Walter A. Redefining Market Orientation from Relational Perspective: Theoretical Considerations and Empirical Results. European Journal of Marketing. 2002;36(9 and 10):1119-1139.

83. Hillery M, Nancarrow G, Griffin, et al. Tourist Perception of Environmental Impact. Annals of Tourism Research. 2001;28(4):853-867.

84. Crotts JC, Buhalis D, March R. New York: The Haworth Hospitality Press; 2000. 178 p.

85. Jamal T, Getz D. Collaboration Theory and Community Planning. Annals of Tourism Research. 1995;22(1):186-204.

86. Kanter RM. Thinking Locally in the Global Economy. USA: Harvard Business Review; 1995. 151-160 p.

87. Porter M. Competitive Strategy. New York: Free Press; 1980.

88. Ashkenas R, Ulrich D, Jick T, et al. The Boundaryless Organisation. San Francisco: Jossey-Bass; 1995. 364 p.

89. Crotts J, Wilson D. An Integrated Model of Buyer-Seller Relationships in the International Travel Trade. Progress in Tourism and Hospitality Research. 1995;1(2):125-140.

90. Beverland M, Brotherton P. The Uncertain Search for Opportunities: Determinants of Strategic Partnerships. Qualitative Market Research: An International Journal. 2001;4(2):88-99. 
91. Bleeke J, Ernst D. Is Your Strategic Alliance Really a Sale? Harvard Business Review. 1995;(January-February):97-103.

92. Bryden J M. Tourism and Development. Cambridge: Cambridge University Press; 1973. 236 p.

93. Chipkin H. Is Independents Day at Hand? Lodging. 2001;26(11):44-48.

94. Christopher M, Payne A, Ballantyne D. Relationship Marketing: Creating Stakeholder Value. Oxford: Butterworth Heinemann; 2002. 242 p.

95. Slattery P, Roper A, Boer A. Hotel Consortia: Their Activities, Structure and Growth. Service Industries Journal. 1985;5(2):192-199.

96. Telfer DJ. Tastes of Niagra: Building Strategic Alliances Between Tourism and Agriculture. 2000;1(1):71-88.

97. Terpstra V, Simonin B. Strategic Alliances in the Triad: An Exploratory Study. Journal of International Marketing. 1993;1(1):4-25.

98. Tisdell C. The Economics of Tourism. Northampton: Edward Elgar Publishing; 2000. 1,126 p.

99. Mathieson, Alister, Geoffrey Wall. Tourism: Economic, Physical and Social Impacts. London: Longman Group Limited; 1982. 208 p.

100. Tribe J. The Economics of Leisure and Tourism. $4^{\text {th }}$ Edition. Oxford Butterworth- Heinemann; 1999. 508 p.

101. Vogel HL. Travel Industry Economics. $2^{\text {nd }}$ edition. Cambridge: Cambridge University Press; 2001. 334 p.

102. Wagner JE. Estimating the Economic Impacts of Tourism. Annals of Tourism Research. 1997;24(3):592-608.

103. Williams, Allan M, Gareth Shaw. Tourism and Economic Development: Western European Experiences. 2nd ed. London: Belhaven Press; 1991. $444 \mathrm{p}$.

104. Donaldson B, O'Toole T. Strategic Marketing Relationships: From Strategy to Implementation. Chichester: John Wiley \& Sons; 2002. 288 p.

105. Eadington WR, Redman M. Economics and Tourism. Annals of Tourism Research. 1991;18(1):41-56.

106. Dogan H Z. Forms of Adjustment: Socio-cultural Impacts of Tourism Annals of Tourism Research. 1989;16(2):216-236.
107. Dann G, Cohen E. Sociology and Tourism. Annals of Tourism Research. 1991;18(1):155-169.

108. Smith VL, Brent M. Hosts and Guests Revisited: Tourism Issues of the $21^{\text {st }}$ Century. New York: Cognizant. 2001. 31 p.

109. Reisinger Y, Turner LW. Cross-Cultural Behaviour in Tourism: Concepts and Analysis. Oxford: Butterworth-Heinemann; 2003. 337 p.

110. Mitchell RE, Reid DG. Community Integration: Island Tourism in Peru. Annals of Tourism Research. 2001;28(1):113-139.

111. Leitner MJ. Promoting Peace Through Intergenerational Tourism. Tourism Recreation Research. 1999;24(1):53-56.

112. Lindberg K, Johnson RL. The Economic Values of Tourism's Social Impacts. Annals of Tourism Research. 1997;24(1):90-116.

113. Manning T. Indicators of Tourism Sustainability. Tourism Management. 1999;20:179-181

114. Morgan RM, Hunt SD. The Commitment-Trust Theory of Relationship Marketing. Journal of Marketing. 1994;58(3):20-38.

115. Morrish SC, Hamilton RT. Airline Alliances-Who Benefits? Journal of Air Transport Management. 2002;8(6):401-407.

116. Nepal SJ. Tourism in Protected Areas: The Nepalese Himalaya. Annals of Tourism Research. 2000;27(3):661-681.

117. Oum TH, Park JH. Airline Alliances: Current Status, Policy Issues, and Future Directions. Journal of Air Transport Management. 1997;3(3):133_ 144.

118. Paci E. Collection and Compilation of Tourism Statistics. Technical Manual No. 4. Madrid: World Tourism; 1992. 3-9 p.

119. Palmer A, Bejou D. Tourism Destination Marketing Alliances. Annals of Tourism Research. 1995;22(3):616-629.

120. Ritchie JRB, Crouch GI. The Competitive Destination: A Sustainable Tourism Perspective. Oxen: CABI Publishing; 2003. 290 p.

121. Sharpley R. Tourism and Sustainable Development: Exploring the Theoretical Divide. Journal of Sustainable Tourism. 2000;8(1):1-19. 